\title{
Evaluating Eco-friendly Potting Media on Growth and Yield of Carrot Varieties in Abakaliki, South Eastern Nigeria
}

\author{
Utobo E.B. ${ }^{1}$, Ekwu L.G. ${ }^{2}$, Nwogbaga A.C. ${ }^{3}$, Nwanchor, K. ${ }^{4}$ \\ Department of Crop Production and Landscape Management, Ebonyi State University, P.M.B. 053, Abakaliki, Nigeria
}

\begin{abstract}
Screen house and field experiments were conducted in 2012 to evaluate the influence of different potting media on the growth and yield of carrot varieties, using $3 x 7$ factorial laid out in a Completely Randomized Design (CRD). Factor A was three (3) different carrot varieties, whereas factor $B$ was seven (7) different potting media. The result revealed that the carrot varieties were significantly different in vegetative and yield parameters measured under both conditions regardless of potting media. Lunga rossa ottusa $2\left(V_{2}\right)$ performed best, followed by Technisem $\left(V_{1}\right)$ and the least was that of Royal Sluis $\left(V_{3}\right)$. In terms of potting media, significant effects were also observed in growth and yield of the three carrot varieties evaluated under both screen house and field conditions respectively. Medium 6 (composted rice hull + composted sawdust + cured pig dung + top soil) performed best under both conditions, followed by media 5 (composted rice hull + cured pig dung + top soil), compared to the rest of the media.
\end{abstract}

Keywords: potting media, carrot, growth, yield, eco-friendly

\section{Introduction}

Carrot (Daucus carota var sativus) is a hardy, cool season, day neutral crop that is mostly grown for the thickened root and for food. It is the most important crop plant of the family Umbeliferae, which is distributed worldwide. The crop has high vitamin A, mineral and dietary fiber contents with characteristic flavour and colour [1], [2]. Among succulent vegetable crops, carrot ranks third in world production [3]. In Nigeria, it is relatively a recent addition to the diet prior to the mid 50s. But, currently the crop has become a common commodity in the Northern part of the Country, particularly at the end of the dry season - March to May; when large quantities are produced and marketed further south, where little of the crop is grown [4]. Carrots prefer fertile, well-drained, deep, sandy soil rich in organic matter, with a $\mathrm{pH}$ of $5.5-7.0$ for best growth. Top growth is reduced at mean air temperature above $28{ }^{\circ} \mathrm{C}$ and the roots become longer tapered below $16{ }^{\circ} \mathrm{C}$. At 4 to $10{ }^{\circ} \mathrm{C}$, there is less root enlargement and very little top growth [3].

It is easy to think of soil as a good medium, but most soils when used alone are very poor growing medium. Soil has been indicated as the easiest way through which seedlings become infected with diseases such as root knot nematode and seedling rots [5]. Carrot can therefore, be grown using potting media as an eco-friendly, innovative alternative instead of soil. Potting media are light-weight substrates used in containers (pots) or poly bags for the production of crops and plants [6]. The materials used in a potting mix can be manipulated or processed to produce a growing medium with superior physical properties to the soil. [7].

In container / poly bags crop production, use of organic potting media substrate offers a great advantage over the conventional topsoil. Organic substrates provide adequate nutrients to the seedling, better root and less pre-dispose the seedlings to soil-borne pests and diseases [8]. Albery [9] reported that sawdust is the most commonly and widely used wood residue in agriculture for potting mixes. However, the decomposition of sawdust causes nitrogen deficiency. Wootton et al. [10] observed that well-composted sawdust is preferred in any potting mix. Rice hull is light in weight, has uniform quality, resistant to decay and depletion of available nitrogen by microorganisms. It has the advantage of being easily incorporated into media for improved drainage and aeration [11]. The physical composition of rice hull can have a profound effect on the supply of water and air to the growing plant as well as affect anchorage, nutrient and water holding capacity of the media [12], [13]. George and Kelvin [7] reported that sawdust and rice hull mixed as a potting medium must be composted. Compost is perhaps the most common potting mix ingredient among organic products. Compost holds water well, provides nutrients and can be made right on the farm. Animal manures and bedding, farm and garden wastes and other materials can be combined to make high-quality reasonably consistent compost [7].

The quality of potting media is important in the successful growing of crops in containers or poly bags. Bunt [14] stated that a good potting medium should meet the needs of plant roots for air, water, nutrient and support. This practice will go a long way to encourage farming in individual or family homes because it makes farming easier and more reliable. Therefore, this study was conducted to evaluate the effect of different potting media mixture on the growth and yield of carrot varieties using poly bag technique and also to select the best potting medium for cultivation of carrot in poly bags, under screen house and field conditions.

\section{Materials and Methods}

The study was conducted in 2012 under screen house and research field of the Department of Crop Production and Landscape Management, Ebonyi State University, Abakaliki, derived savannah zone of South Eastern Nigeria (Lat. $06^{0} 45^{\mathrm{I}} \mathrm{N}$ and Long. $08^{0} 30^{\mathrm{I}} \mathrm{E}$ and elevation of $447 \mathrm{~m}$ above the sea level). The total rainfall ranges from $1700 \mathrm{~mm}$ $-2000 \mathrm{~mm}$, annual mean temperature is between $22{ }^{\circ} \mathrm{C}$ to 32 ${ }^{0} \mathrm{C}$ and humidity ranges from $60 \%$ to $90 \%$. 


\section{International Journal of Science and Research (IJSR) ISSN (Online): 2319-7064 \\ Index Copernicus Value (2013): 6.14 | Impact Factor (2015): 6.391}

Before the media preparation, some selected properties of the solarized top soil used in media formulation and as a control were analyzed and presented in Table 1. Different types of potting media were prepared using composted sawdust (CSD), composted rice hull (CRH), cured pig dung (CPD) and solarized top soil (TS) in different ratios ( $\mathrm{v} / \mathrm{v}$ basis) as shown in Table 2. The media mixtures were allowed to cure further for two weeks in poly bags before planting. The three carrot varieties used were Technisem $\left(\mathrm{V}_{1}\right)$, Lunga rossa ottusa $2\left(\mathrm{~V}_{2}\right)$ and Royal sluis $\left(\mathrm{V}_{3}\right)$

The experimental design was $3 \times 7$ factorial laid out in a Completely Randomized Design (CRD). This gave twenty one (21) treatment combinations that were replicated three times to produce a total of 63 experimental pots. Factor A were the three (3) different carrot varieties and factor B were the seven (7) different potting media mixture. Planting was done in poly pots $\left(15 \times 15 \times 30 \mathrm{~cm}^{3}\right)$ containing different potting media mixtures. The seed rate was six seeds per pot which was thinned down to three after germination. Water was applied once a day to supply adequate moisture to the crops and weeding was carried out as the need arose. The experiment was replicated under field conditions.

The average of the vegetative growth (plant height, number of leaves, number of branches, and leave weight), yield components (root length and root circumference) and root yield parameters were computed.

All data collected were subjected to analysis of variance (ANOVA) to test for the significance of treatment effects using GenStat Discovery Edition software version 3.0 for Windows [15]. The treatment means were compared using the least significant difference (LSD) test at a significance level of 0.05 .

Table 1: Some selected properties of top soil used for the

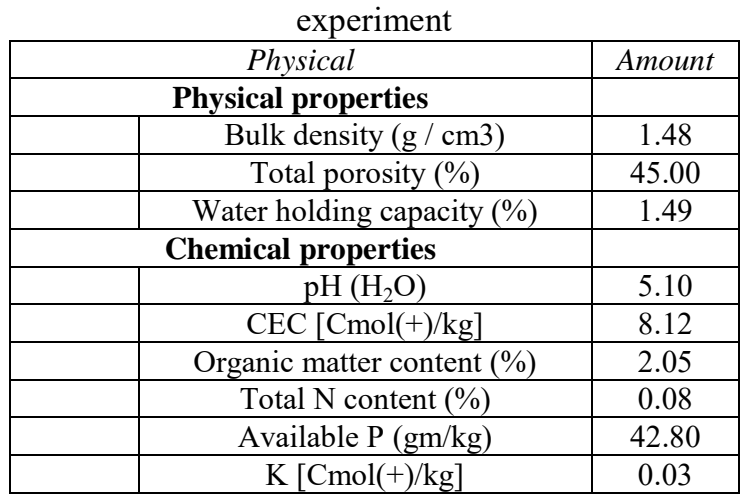

Table 2: Potting media composition

\begin{tabular}{|c|c|}
\hline $\mathbf{S} / \mathbf{N}$ & Media composition / Ratio (v/v) \\
\hline M1 & Composted sawdust + Cured pig dung (CSD + CPD)/ $3: 1$ \\
\hline M2 & Composted rice hull + Cured pig dung $(\mathrm{CRH}+\mathrm{CPD}) / 3: 1$ \\
\hline M3 & $\begin{array}{c}\text { Composted sawdust + Composted rice hull + Cured pig dung } \\
(\text { CSD }+ \text { CRH }+ \text { CPD }) / 1.5: 1.5: 1\end{array}$ \\
\hline M4 & $\begin{array}{c}\text { Composted sawdust + Cured pig dung + Top soil (CSD + } \\
\text { CPD+ TS) } / 1.5: 1.5: 1\end{array}$ \\
\hline M5 & $\begin{array}{l}\text { Composted rice hull }+ \text { Cured pig dung }+ \\
\text { Top soil }(\mathrm{CRH}+\mathrm{CPD}+\mathrm{TS}) / 1.5: 1.5: 1\end{array}$ \\
\hline M6 & $\begin{array}{c}\text { Composted sawdust + Composted rice hull +Cured pig dung } \\
\text { +Top soil (CSD + CRH }+ \text { CPD + TS }) / 1: 1: 1: 1\end{array}$ \\
\hline M7 & Top soil (CONTROL) / 4 \\
\hline
\end{tabular}

\section{Results and Discussion}

\subsection{Effect of Variety}

The carrot varieties were significantly different in some vegetative parameters measured under screen house and field conditions respectively (Table 3 ). Luga rossa ottusa 2 $\left(\mathrm{V}_{2}\right)$ and Technisem $\left(\mathrm{V}_{1}\right)$ produced plants that were statistically similar in terms of plant height $(40.41 \mathrm{~cm}$ and $39.60 \mathrm{~cm}$ respectively), but $\mathrm{V}_{2}$ was significantly different from Royal sluis $\left(\mathrm{V}_{3}\right)$ while $\mathrm{V}_{1}$ and $\mathrm{V}_{3}(37.1 \mathrm{~cm})$ were statistically similar in screen house conditions. Under field conditions, $\mathrm{V}_{2}$ produced the tallest plant $(31.31 \mathrm{~cm})$ which differed significantly from $V_{1}(29.79 \mathrm{~cm})$ and $V_{3}(29.70 \mathrm{~cm})$ respectively. Number of leaves were significantly better for $\mathrm{V}_{2}$ in both screen house (95.40) and field (75.56) conditions, when compared to $\mathrm{V}_{1}$ (91.20 and 67.69) and V3 (86.00 and 69.12) respectively. As regards the number of branches, $V_{2}$ and $\mathrm{V}_{1}$ produced similar results under screen house conditions (10.24 and 10.05 respectively) which differed significantly from $\mathrm{V}_{3}(9.14)$, while under field condition, $\mathrm{V}_{2}$ produced a number of leaves (75.56) which was significantly higher than $V_{1}(67.69)$ and $V_{3}$ (69.12). Weight of leaves on the other hand was not significant under screen house conditions, but in the field, $\mathrm{V}_{2}$ also produced higher leaf weight of $38.00 \mathrm{~g} /$ pot which differed significantly from $\mathrm{V}_{1}(34.59 \mathrm{~g} /$ pot $)$ and $\mathrm{V}_{3}(35.79 \mathrm{~g} /$ pot $)$.

The carrot varieties evaluated were significantly different, in terms of yield and yield components measured only under field conditions (Table 4). $\mathrm{V}_{2}$ produced plants whose root length $(12.60 \mathrm{~cm})$ and root circumference $(9.99 \mathrm{~cm})$ were significantly better than $\mathrm{V}_{1}(10.96 \mathrm{~cm}$ and $8.95 \mathrm{~cm})$ and $\mathrm{V}_{3} .(9.79 \mathrm{~cm}$ and $8.39 \mathrm{~cm})$ respectively. $\mathrm{V}_{2}$ and $\mathrm{V}_{1}$ produced plants that were statistically similar in terms of root yield $\left(0.09 \mathrm{~kg} /\right.$ pot and $0.07 \mathrm{~kg} /$ pot respectively), but $\mathrm{V}_{2}$ was significantly different from $\mathrm{V}_{3}(0.06 \mathrm{~kg} / \mathrm{pot})$ unlike $\mathrm{V}_{1}$ and $\mathrm{V}_{3}$ which showed statistical similarity. The results showed that Luga rossa ottusa $2\left(\mathrm{~V}_{2}\right)$ performed best followed by Technisem $\left(\mathrm{V}_{1}\right)$ and the least was that of Royal sluis $\left(\mathrm{V}_{3}\right)$, in terms of growth and yield attributes. These observed differences according to Ibrahim et al. [16] are normally attributed to their genetic makeup. Akande and Lamidi [17] also observed that different characteristics are controlled by the different gene action and so behave differently in giving environment.

\subsection{Effect of Potting Media}

The potting media mixture significantly affected all the vegetative growth parameters measured both in screen house and field conditions (Table 3). Medium 6 performed best for plant height under screen house $(42.82 \mathrm{~cm})$ and field $(31.94$ $\mathrm{cm})$, and was similar to medium $3(41.70 \mathrm{~cm}$ and $30.77 \mathrm{~cm})$, and medium $5(41.50 \mathrm{~cm}$ and $30.93 \mathrm{~cm})$ respectively, but differed significantly from the rest of the media. Similarly, for the number of leaves, medium 6 also performed best under both conditions (103.11 and 69.57), but did not differ significantly from media 3 (96.33 and 56.81) and 5(96.00 and 62.56) respectively unlike the rest of the media. As regards to number of branches, medium 5 did best under both screen house (10.89) and field (7.20) conditions which showed statistical similarity with media 2 (9.78 and 6.43), 3 


\section{International Journal of Science and Research (IJSR) \\ ISSN (Online): 2319-7064 \\ Index Copernicus Value (2013): 6.14 | Impact Factor (2015): 6.391}

(10.56 and 6.23), 4 (9.67 and 6.93) and 6 (10.67 and 6.67). For leaf weight, medium 6 performed best under screen house $(44.86 \mathrm{~g} / \mathrm{pot})$ and field $(42.21 \mathrm{~g} / \mathrm{pot})$ conditions and were similar to media 5 (44.26 g/pot and $40.53 \mathrm{~g} / \mathrm{pot})$, but differed significantly from the rest of the media.

Media also significantly affected the entire yield and yield parameters measured under both screen house and field conditions (Table 4). For root length, medium 6 performed best under screen house $(13.96 \mathrm{~cm})$ and field $(13.67 \mathrm{~cm})$ conditions, which was similar to medium 5 under both conditions $(13.41 \mathrm{~cm}$ and $13.23 \mathrm{~cm})$ but differed significantly from the rest of the media, except in the field where medium 6 was statistically similar to media 3 and 4 . Also, under both conditions, medium 6 performed best in terms of root circumference $(11.82 \mathrm{~cm}$ and $10.17 \mathrm{~cm})$, and yield $(0.12 \mathrm{~kg} /$ plot and $0.10 \mathrm{~kg} /$ pot $)$ respectively but differed significantly from the rest of the media. These results suggest that media 6 (composted sawdust + rice hull + pig dung + river sand) performed best generally followed by medium 5 (composted rice hull + pig dung + river sand) in terms of growth and yield parameter measured. A similar result was obtained by Mumtazkhan et al. [18]. They observed that the media containing sand + peat + spent compost of button mushroom $(1: 1: 1)$ proved to be a superior potting medium for growth of rough lemon (C. jambhiri) nursery stock. Anvari et al. [19] also observed that potting media containing sand, manure, clay loam, and saw dust were found effective for the healthy growth and development of Troyer citrange grown in pots. These results were supported by the finding of World bank [20] who observed that mixtures of various components with complementary physical and chemical properties will produce superior potting media necessary for growth and yield of crops.

\section{Conclusion and Recommendation}

Potting media had a significant effect on some of the vegetative and yield parameters of three carrot varieties evaluated. Mixtures of various components

Table 3: Effects of varieties and media on carrot plant height $(\mathrm{cm})$, number of branches, number of leaves and weight of leaves

\begin{tabular}{|c|c|c|c|c|c|c|c|c|}
\hline & \multicolumn{3}{|c|}{ Screen house } & & \multicolumn{3}{|c|}{ Field } & \multirow[b]{2}{*}{$\begin{array}{c}\text { Weight of leaves } \\
\text { (g/pot) }\end{array}$} \\
\hline Treatments & \begin{tabular}{c|} 
Plant \\
height $(\mathrm{cm})$
\end{tabular} & $\begin{array}{l}\text { No. of } \\
\text { leaves }\end{array}$ & \begin{tabular}{|c|}
$\begin{array}{c}\text { No. of } \\
\text { branches }\end{array}$ \\
\end{tabular} & $\begin{array}{c}\text { Weight of leaves } \\
\text { (g/pot) }\end{array}$ & \begin{tabular}{|c|} 
Plant \\
Height $(\mathrm{cm})$ \\
\end{tabular} & \begin{tabular}{|l|}
$\begin{array}{l}\text { No. of } \\
\text { leaves }\end{array}$ \\
\end{tabular} & \begin{tabular}{|c|}
$\begin{array}{c}\text { No. of } \\
\text { branches }\end{array}$ \\
\end{tabular} & \\
\hline \multicolumn{9}{|l|}{ Varieties (V) } \\
\hline Technisem $\left(\mathrm{V}_{1}\right)$ & $39.60 \mathrm{ab}$ & $91.21 \mathrm{~b}$ & $10.05 \mathrm{ab}$ & 40.35 & $29.79 b$ & $67.69 \mathrm{~b}$ & $7.60 \mathrm{~b}$ & $34.59 \mathrm{~b}$ \\
\hline Luga rossa ottusa $2\left(\mathrm{~V}_{2}\right)$ & $40.41 \mathrm{a}$ & $95.40 \mathrm{a}$ & $10.24 \mathrm{a}$ & 40.48 & $31.31 \mathrm{a}$ & $75.56 \mathrm{a}$ & $7.96 \mathrm{a}$ & $38.00 \mathrm{a}$ \\
\hline Royal sluis $\left(\mathrm{V}_{3}\right)$ & $37.10 \mathrm{~b}$ & $86.00 \mathrm{~b}$ & $9.14 b$ & 35.71 & $29.70 \mathrm{~b}$ & $69.12 b$ & $7.11 \mathrm{c}$ & $35.79 b$ \\
\hline $\operatorname{LSD}_{(0.05)}$ & $2.69 * *$ & $6.49 * *$ & $0.87 *$ & NS & $1.33^{*}$ & $3.43 *$ & $0.18^{*}$ & $2.17 *$ \\
\hline \multicolumn{9}{|l|}{ Media (M) } \\
\hline $\mathrm{M}_{1}$ & $30.31 \mathrm{~d}$ & $63.72 \mathrm{~d}$ & $8.00 \mathrm{c}$ & $33.29 \mathrm{c}$ & $29.43 b$ & $51.43 \mathrm{e}$ & $6.40 \mathrm{bc}$ & $33.78 \mathrm{~d}$ \\
\hline $\mathrm{M}_{2}$ & $39.12 \mathrm{c}$ & $88.81 \mathrm{~b}$ & $9.78 \mathrm{a}$ & $38.15 b$ & $30.60 \mathrm{ab}$ & $58.38 \mathrm{~cd}$ & $6.43 b$ & $37.75 \mathrm{c}$ \\
\hline $\mathrm{M}_{3}$ & $41.70 \mathrm{ab}$ & $96.33 \mathrm{a}$ & $10.56 \mathrm{a}$ & $37.67 \mathrm{~b}$ & $30.77 \mathrm{a}$ & $56.81 \mathrm{~d}$ & $6.23 \mathrm{c}$ & $36.14 \mathrm{c}$ \\
\hline $\mathrm{M}_{4}$ & $40.33 b$ & $87.30 \mathrm{bc}$ & $9.67 \mathrm{ab}$ & $38.19 \mathrm{~b}$ & $30.73 a$ & $58.80 \mathrm{bc}$ & $6.93 \mathrm{ab}$ & $40.39 \mathrm{~b}$ \\
\hline $\mathrm{M}_{5}$ & $41.50 \mathrm{a}$ & $96.00 \mathrm{ab}$ & $10.89 \mathrm{a}$ & $44.26 \mathrm{a}$ & $30.93 a$ & $62.56 \mathrm{~b}$ & $7.20 \mathrm{a}$ & $40.53 \mathrm{ab}$ \\
\hline $\mathrm{M}_{6}$ & $42.82 \mathrm{a}$ & $103.11 \mathrm{a}$ & $10.67 \mathrm{a}$ & $44.96 \mathrm{a}$ & $31.94 \mathrm{a}$ & \begin{tabular}{|l|}
$69.57 \mathrm{a}$ \\
\end{tabular} & $6.97 \mathrm{a}$ & $42.21 \mathrm{a}$ \\
\hline $\mathrm{M}_{7}$ & $37.51 \mathrm{c}$ & $77.73 \mathrm{~cd}$ & $9.11 b c$ & $34.79 \mathrm{c}$ & $27.47 \mathrm{c}$ & \begin{tabular}{|l|}
$50.96 \mathrm{e}$ \\
\end{tabular} & $6.03 c$ & $33.87 \mathrm{~d}$ \\
\hline $\operatorname{LSD}_{(0.05)}$ & $1.76 * *$ & $10.79 * *$ & $1.32 * *$ & $1.78 *$ & $1.72 *$ & $4.41 * *$ & $0.54 *$ & $1.70 * *$ \\
\hline
\end{tabular}

Table 4: Effects of varieties and media on carrot root length, root circumference, and yield (kg/plot)

\begin{tabular}{|c|c|c|c|c|c|c|}
\hline & \multicolumn{3}{|c|}{ Screen house } & \multicolumn{3}{|c|}{ Field } \\
\hline Treatments & $\begin{array}{c}\text { Root } \\
\text { Length }(\mathrm{cm})\end{array}$ & $\begin{array}{c}\text { Root } \\
\text { circumference }(\mathrm{cm})\end{array}$ & Root yield (kg/plot) & $\begin{array}{c}\text { Root } \\
\text { Length }(\mathrm{cm})\end{array}$ & $\begin{array}{c}\text { Root } \\
\text { circumference }(\mathrm{cm})\end{array}$ & $\begin{array}{c}\text { Root yield } \\
\text { (kg/plot) }\end{array}$ \\
\hline \multicolumn{7}{|l|}{ Varieties (V) } \\
\hline Technisem $\left(\mathrm{V}_{1}\right)$ & 13.72 & 10.73 & 0.15 & $10.96 \mathrm{~b}$ & $8.95 \mathrm{~b}$ & $0.07 \mathrm{ab}$ \\
\hline Luga rossa ottusa $2\left(\mathrm{~V}_{2}\right)$ & 14.03 & 10.02 & 0.14 & $12.60 \mathrm{a}$ & $9.99 \mathrm{a}$ & $0.09 \mathrm{a}$ \\
\hline Royal sluis $\left(\mathrm{V}_{3}\right)$ & 13.51 & 9.81 & 0.13 & $9.79 \mathrm{~b}$ & $8.39 \mathrm{~b}$ & $0.06 \mathrm{~b}$ \\
\hline $\operatorname{LSD}_{(0.05)}$ & NS & NS & NS & $1.59 *$ & $1.03 *$ & $0.02 *$ \\
\hline \multicolumn{7}{|l|}{ Media (M) } \\
\hline $\mathrm{M}_{1}$ & $11.32 \mathrm{~d}$ & $8.61 \mathrm{e}$ & $0.06 \mathrm{de}$ & $10.87 \mathrm{~b}$ & $7.57 \mathrm{c}$ & $0.06 \mathrm{~d}$ \\
\hline $\mathrm{M}_{2}$ & $12.13 \mathrm{c}$ & $9.92 \mathrm{~d}$ & $0.07 \mathrm{~cd}$ & $11.93 \mathrm{ab}$ & $8.43 b c$ & $0.06 \mathrm{~d}$ \\
\hline $\mathrm{M}_{3}$ & $12.44 \mathrm{c}$ & $9.94 d$ & $0.08 \mathrm{bc}$ & $12.37 \mathrm{a}$ & $8.67 \mathrm{~b}$ & $0.07 \mathrm{c}$ \\
\hline $\mathrm{M}_{4}$ & $12.63 \mathrm{~b}$ & $10.23 \mathrm{c}$ & $0.08 \mathrm{bc}$ & $12.47 \mathrm{a}$ & $9.10 \mathrm{ab}$ & $0.07 \mathrm{c}$ \\
\hline $\mathrm{M}_{5}$ & $13.41 \mathrm{a}$ & $11.12 \mathrm{~b}$ & $0.10 \mathrm{~b}$ & $13.23 \mathrm{a}$ & $9.40 \mathrm{a}$ & $0.09 \mathrm{~b}$ \\
\hline $\mathrm{M}_{6}$ & $13.96 \mathrm{a}$ & $11.82 \mathrm{a}$ & $0.12 \mathrm{a}$ & $13.67 \mathrm{a}$ & $10.17 \mathrm{a}$ & $0.10 \mathrm{a}$ \\
\hline $\mathrm{M}_{7}$ & $9.71 \mathrm{c}$ & $8.33 \mathrm{e}$ & $0.05 \mathrm{e}$ & $8.97 \mathrm{c}$ & $7.50 \mathrm{c}$ & $0.05 \mathrm{e}$ \\
\hline $\operatorname{LSD}_{(0.05)}$ & $1.34 * *$ & $0.55 * *$ & $0.016^{*}$ & $1.70 *$ & $1.33 * *$ & $0.004 * *$ \\
\hline
\end{tabular}




\section{International Journal of Science and Research (IJSR) \\ ISSN (Online): 2319-7064 \\ Index Copernicus Value (2013): 6.14 | Impact Factor (2015): 6.391}

with complementary physical and chemical properties which produced superior potting media such as 6 (composted rice hull + composted sawdust + cured pig dung + top soil $)$, followed by media 5 (composted rice hull + cured pig dung + top soil) were more productive compared to the rest potting mixtures, and should be used in the production of carrot under controlled and field conditions in Abakaliki, Southeastern Nigeria. For best production, screen house will be preferred, with carrot variety Luga rossa ottusa $2\left(\mathrm{~V}_{2}\right)$ followed by Technisem $\left(\mathrm{V}_{1}\right)$.

\section{Acknowledgement}

I acknowledge the effort of Mozia, Maranatha L. and Nnamani Patience F., who ensured that this research work was accomplished.

\section{References}

[1] Mills, H.A. Vegetable crops: carrot (Daucus carota L. spp. Sativus) college of Agricultural and Environmental sciences, university of Georgia, 2001.

[2] United Nations, Organic Fruit and Vegetable from the Tropics: Market. Certification and Production Information for Producers and International Trading Companies. Pp. 330, 2003.

[3] Ahmed, A., Sambo, B. E., Arunah, U. L. and Odion, E. C. Response of Farmyard Manure and Inorganic Fertilizers for Sustainable Growth of Carrot (Daucus carota L.) in Northern Nigeria. IOSR Journal of Agriculture and Veterinary Science, 7(2):18-25, 2014.

[4] Sarkindiya, S. and Yakubu, A. I. Effect of Intra-row Spacing, Fertilizer Level and Period of Weeding on the Performance of Carrot (Daucus carota L.) in Sokoto Rima Valley, Sav. J. of Agric., 1 (1): 1-5, 2006.

[5] Egunjobi O.A. and Ekundare, O.O. The cassava peeling as a soil amendment and its effects on maize yield in soil infested with pratylenchus bractyams. Nig J plant prod., 5:80-87,1981.

[6] McGinnis, M., Cleveland, B. and Strokes, C. Flinculture, nursery and greenhouse crops. Sampling for soilless media analysis. North Carolinas department of Agriculture and consumer services Agronomic sampling folder no.9 www.neagrogov/agronomil. 2009.

[7] George, K. and Kelvin, E. Potting mixes for certified organic production. National sustainable agriculture information service, Horticultural technical note. www.altrarncat.org. 2004.

[8] Akanbi, B.W., Togum A.O. and Baiyeri, R.A. Suitability of plant residue compost as nursery medium for some tropical friut tree seedlings. Mar J. Agric. Res., 3: 24-29, 2002.

[9] Albery, P.E. Sawdust as container growing medium. Combined proceedings of plants propagator society, 25: 272-275, 1975.

[10] Wootton, R.D., Gouin, F.R. and Stark, F.C. Composted, digested sludge as a medium for growing flowering annuals. J. Amer. Soc. Hort. Sci., 106: 46-49, 1981.

[11] Wilkerson, D., Barnes, L., Drees, B. and Hall, C. The Texas Poinsettia Producers Guide: Selecting a Growing Medium. Texas Agricultural Extension Service Greenhouse Bulletin. 1994.
[12] Beardsell, D.U. and Michols, D. Wetting properties of dried-out nursery container media. Scientia Horticulture, 17:49-59, 1982.

[13] Baiyeri, K.P. Response of Musa species on macropropagation. II: the effect or genotype, initiative and weaning media on sucker growth and quality in the nursery. African journal of Biotechnology, 4 (3) 229234, 2005.

[14] Bunt, A.C. Media and mixes for container grown plants. A manual on the preparation and use of growing media for pot plants $\left(2^{\text {nd }} \mathrm{Ed}\right)$. Uwing Hyman Ltd. London. Pp. $307,1988$.

[15]GenStat Inc. GenStat Discovery Edition 3. - VSN International Ltd. 2008.

[16] Ibrahim, R., Amans, E.B., Ahmed, A. and Abubakar, I.U. Growth and yield of tomato (Lylopersicum esculentum Mill) varieties influenced by crop spacing at Samaru, Northern Nigeria. Nig. J. Hort Sc., 5:52-57, 2001.

[17] Akande, S.R. and Lamidi, G.O. Performance of quality protein maize varieties and disease reaction in the derived Savanna agro-ecology of South West Nigeria. Institute of Agricultural Research and Training, Obafemi Awolowo University, moor plantation, Ibadan, Nigeria. Pp 1-4, 2006.

[18] Mumtazkhan, M., Azamkhan, M., Mazhar, A., Muhammed, J. Jaskani, M.A. and Haider, A. Evaluation of potting media for the production of rough lemon nursery stock. 38(3): 623-629, 2006.

[19] Anvari, F.Y., Ebrahimi, Y.M., Aliyan, S.N. and Vahidi, $\mathrm{K}$. An evaluation of eight media for propagation of citrus nursery trees in containers in northern Iran. Proc. Int. Soc.. Citriculture, 1:307-308, 1992.

[20] World Bank. Organic and Compost-based Growing Media for Tree Seedling Nurseries. 1995. 